\title{
SOIL CARBON STOCK CHANGES IN TRANSITIONAL MIRE DRAINED FOR FORESTRY IN LATVIA: A CASE STUDY
}

\author{
Ainars Lupikis, Andis Lazdins \\ Latvian State Forest Research Institute 'Silava' \\ ainars.lupikis@silava.lv
}

\begin{abstract}
The aim of the study is to evaluate the impact of drainage on soil carbon stock in a transitional mire drained for forestry. The study site is located in the central part of Latvia representing hemiboreal vegetation zone. Site was drained in 1960. It is located in a catchment area of the river Veseta. An undrained site at the same catchment area was chosen for control (ca. $2.5 \mathrm{~km}$ between sites). In both sites, the depth of peat is $4-4.5 \mathrm{~m}$. Drained site is dominated by coniferous trees. Soil samples collected in 2014 were used to determine bulk density and carbon content, and to calculate soil carbon stock. Samples were collected down to $80 \mathrm{~cm}$ depth. Ground surface elevation was measured before and several times after the drainage to determine peat subsidence.

Carbon stock has increased by 0.3 tons $\mathrm{ha}^{-1} \mathrm{yr}^{1}$ after drainage, although peat has subsided on average by $26 \mathrm{~cm}$ $(13-48 \mathrm{~cm})$. Subsidence was mainly caused by physical shrinkage of peat not by organic matter oxidation. Drainage was followed by compaction of aerated soil layer, which has caused most of the subsidence, especially during the first years after drainage. Soil bulk density has increased almost twice at soil surface layer $0-10 \mathrm{~cm}$ (from $75 \mathrm{~kg} \mathrm{~m}^{3}$ to $141 \mathrm{~kg} \mathrm{~m}^{3}$ ). Differences decrease at deeper sampling depths.

It is concluded that drainage is not always followed by reduction of carbon stock in soil. Increased above and below ground litter production rates may offset accelerated decomposition of organic matter after drainage.

Key words: drainage, carbon, organic soil, forestry.
\end{abstract}

\section{Introduction}

Organic soils store large carbon stock and are important carbon pools in the global carbon cycle (Gorham, 1991; Turunen et al., 2002; Yu et al., 2010). Management of organic soils may alter carbon cycling. The main threat for carbon storage is drainage, causing increased $\mathrm{CO}_{2}$ emissions (Minkkinen et al., 2002; Hooijer et al., 2009). Drainage helps to remove the excess water and, consequently, the upper soil layer is enriched with oxygen. It accelerates the decomposition of organic matter (Lieffers, 1988; Bridgham et al., 1991). Soil surface aeration and increased amount of available nutrients for plants due to decomposition (Laiho \& Laine, 1994; Indriksons, 2009) contribute to better plant growth.

In order to increase forest productivity, drainage is widely used in forestry, especially in the northern hemisphere (Zoltai \& Martikainen, 1996). On one hand, the benefits of drainage on forest productivity are evident; it results in a better tree growth (Minkkinen et al., 1999; Zalitis \& Indriksons, 2009). On the other hand, there may be negative consequences to soil carbon storage (Simola, Pitkänen, \& Turunen, 2012; Pitkänen, 2013; Hommeltenberg et al., 2014). On the contrary, some authors have found that carbon stock in forest organic soils can remain stable or even continue to increase after drainage (Minkkinen \& Laine, 1998b). One of the main drivers determining, whether forest organic soil will be carbon source or sink after drainage, is climatic variables. In the boreal vegetation zone drained organic soils in forest often continue to act as a sink (Minkkinen \& Laine, 1998b; Flanagan \& Syed, 2011; Lohila et al., 2011; Ojanen,
Minkkinen, \& Penttilä, 2013), at the same time soil carbon stock on boreal forest peatlands may also decrease (Arnold et al., 2005a; Lohila et al., 2007; Simola et al., 2012). Such differences are partly driven by soil fertility and tree stand type (Minkkinen \& Laine, 1998b; Arnold et al., 2005b, 2005a; Minkkinen et al., 2007; Ojanen et al., 2010). Towards south, in temperate regions, drained organic soil is a net source of $\mathrm{CO}_{2}$ emissions (Cannell, Dewar, \& Pyatt, 1993; Hargreaves, Milne, \& Cannell, 2003; Byrne \& Farrell, 2005; Hommeltenberg et al., 2014). In some cases, emissions from soil can be large enough to turn the whole drained forest ecosystem into $\mathrm{CO}_{2}$ emitter, especially in the long term (Hommeltenberg et al., 2014). On a broad scale, carbon loss from organic soil in temperate climate conditions is larger than in the boreal region (Armentano \& Menges, 1986). No evidence of soil carbon or ecosystem net sink after drainage can be found for tropical climate (Hirano et al., 2008; Sundari et al., 2012; Jauhiainen et al., 2014). Drainage of tropical peatlands may result in extreme $\mathrm{CO}_{2}-\mathrm{C}$ emissions (Comeau et al., 2013).

The impact of climate on carbon loss is clearly displayed in the Intergovernmental Panel of Climate Change (IPCC) guidelines for greenhouse gas (GHG) reporting (Hiraishi et al., 2014) in wetlands supplement. It is stated by default emission factors that net soil $\mathrm{CO}_{2}-\mathrm{C}$ emissions in drained forests increase from boreal climate to tropical climate.

There is a number of publications concerning soil carbon storage in boreal, temperate and tropical climate conditions, but not for the hemiboreal zone. Only few studies deal with hemiboreal drained 
peatlands (Minkkinen et al., 2007; Salm et al., 2012). It is obvious that the carbon cycle alterations after drainage is strongly affected by climate.

The aim of this study is to analyze the impact of drainage for forestry to soil carbon stock changes in a transitional mire which is located in hemiboreal vegetation zone in Latvia.

\section{Materials and Methods}

The study site is located in the central part of Latvia (N 56.7064; E 25.8544) in a catchment area of the river Veseta. This site was initially a transitional mire and it corresponds to hemiboreal vegetation zone. It was drained in 1960, and in 1963 a forest research station was established in this area. A closely located ( $\sim 2.5 \mathrm{~km}$ from the drained site) undrained site in the same catchment was used as a control site. Peat depth on both sites is $4-4.5 \mathrm{~m}$. Before the drainage, the site was dominated by pine trees with an average growing stock $50 \mathrm{~m}^{3} \mathrm{ha}^{-1}$. Currently, the area is covered by pine and spruce forest (Zalitis, Jansons, \& Indriksons, 2012) with an average growing stock $200-250 \mathrm{~m}^{3} \mathrm{ha}^{-1}$. The age of tree stand in drained site is $40-110$ years. Site type is Myrtillosa turf. mel., according to the Latvian forest type classification system. This is ranked as third (out of four) most fertile forest type in the class of drained forests on organic soils.

In total, 20 sample plots $\left(500 \mathrm{~m}^{2}\right)$ in the drained site and 10 sample plots in the control site were established near the ground surface measurement points and ground water wells installed in 1963. Sample plots are located at different distances from the drainage ditches. Soil volumetric samples and litter layer samples were collected in 3 replicates at each sample plot in 2014. Soil samples were collected at four depths: $0-10 \mathrm{~cm}, 10-20 \mathrm{~cm}, 20-40 \mathrm{~cm}$ and $40-80 \mathrm{~cm}$. The volume of each sample was $100 \mathrm{~cm}^{3}$. Litter samples were collected with $10 \times 10 \times 10 \mathrm{~cm}$ steel boxes. Diameter and height of trees were measured at each sample plot. Ground surface elevation was measured before (1960) and several times after $(1966,1970,1972,1975,2014)$ the drainage with an optical level tool. Each time the same reference and measurement points were used.

Soil and litter samples were dried at $105{ }^{\circ} \mathrm{C}$ until constant mass. Carbon content was determined with LECO CR 12 analyzer at a temperature higher than $900{ }^{\circ} \mathrm{C}$.

Soil samples were used to determine dry bulk density $\left(\mathrm{kg} \mathrm{m}^{-3}\right)$ and carbon content $\left(\mathrm{g} \mathrm{C} \mathrm{kg}^{-1}\right)$ which was further used to calculate carbon stock (tons ha-1) in the soil. Peat subsidence was considered when calculating carbon stock changes. Carbon stock at the control site is equal to soil carbon stock in $0-80 \mathrm{~cm}$ soil profile. Carbon stock at the drained site is equal to carbon stock in soil profile of $0-(80-x)$, where $\mathrm{x}$ is subsidence in $\mathrm{cm}$. Carbon stock changes were calculated as a difference of carbon stock between the profiles at the drained $(0-80-\mathrm{x} \mathrm{cm})$ and control $(0-$ $80 \mathrm{~cm})$ site.

Stand volume was calculated as a sum of volume of individual trees (Liepa, 1996) to describe the effect of drainage on a tree stand productivity (1):

$$
M=\sum\left(\psi * h_{i}^{\alpha} * d_{i}^{\beta * l g h_{i}+\varphi}\right)
$$

Where $\psi, \alpha, \beta, \varphi-$ tree specific stem volume coefficient

$\mathrm{h}_{\mathrm{i}}$ - height of $\mathrm{i}$ tree, $\mathrm{m}$

$\mathrm{d}_{\mathrm{i}}$ - diameter of $\mathrm{i}$ tree, $\mathrm{cm}$.

Confidence interval for normal distribution at $\alpha=$ 0.05 was calculated to evaluate statistical difference of average carbon stock between the drained and control site. It was assumed that carbon stock data follows the normal distribution, although the data does not fulfill all the criteria of normal distribution. The same approach was used to calculate confidence interval for bulk density and carbon content.

\section{Results and Discussion}

The depth of peat has decreased by $13-41 \mathrm{~cm}$ (on average by $26 \mathrm{~cm}$ ) 54 years after drainage. The annual subsidence rate is around $0.5 \mathrm{~cm} \mathrm{yr}^{-1}$. These results are comparable with $22 \mathrm{~cm}$ published by Minkkinen and Laine (1998b) and $14-43 \mathrm{~cm}$ published by Lukkala (1949), both studies were carried out in Finland. A lower rate of subsidence ( $8 \mathrm{~cm}$ on average) was observed by Rothwell (1996) in Canada's boreal peatlands. This author emphasizes the impact of ditch spacing to subsidence rate. Peat subsidence occurs faster if the ditch spacing is smaller. Subsidence is strongly variable along the climate and fertility gradient. Leifeld (2011) reports subsidence of $0.8-1.6$ $\mathrm{cm} \mathrm{yr}^{-1}$ on temperate fens. More extreme values have been reported from tropical regions, where subsidence rate can be as high as $2-7 \mathrm{~cm} \mathrm{yr}^{-1}$ (Wösten, Ismail, \& van Wijk, 1997; Schipper \& McLeod, 2002; Hooijer et al., 2012).

Most of the subsidence took place during the first years after drainage $-11 \mathrm{~cm}$ after 6 years and $16 \mathrm{~cm}$ after 15 years (Figure 1). A similar trend was observed also by Lukkala (1949). After the drainage, the subsidence is rapid and it ceases later.

The main reason for subsidence during the first years after the drainage is the physical peat shrinkage after ground water level dropdown but not the peat oxidation, as it is sometimes stated. This hypothesis is confirmed by an increased soil bulk density and increased total carbon stock in the soil. Carbon storage 54 years after drainage has increased 


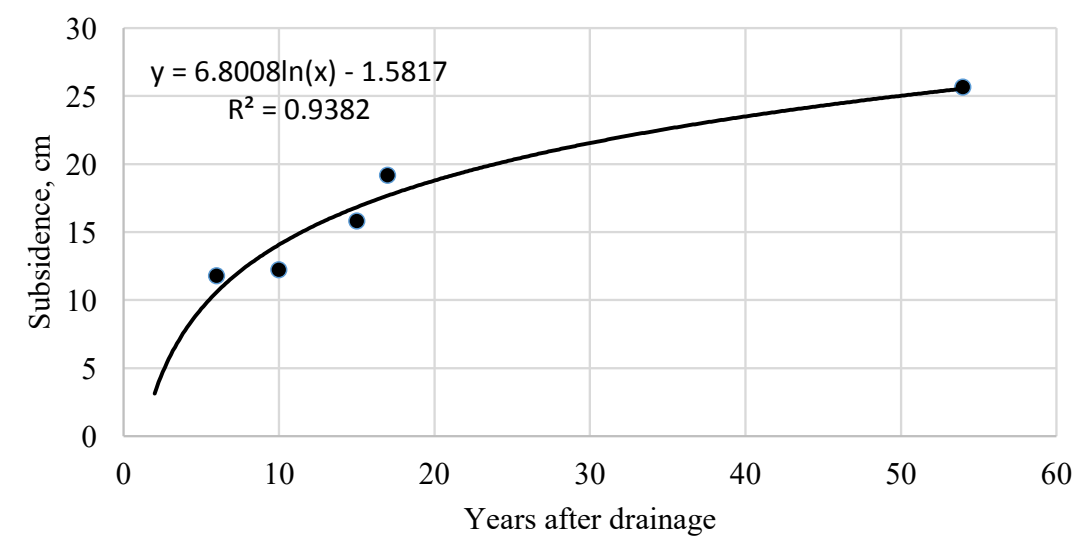

Figure 1. Peat subsidence after drainage.

by 0.3 tons $\mathrm{ha}^{-1} \mathrm{yr}^{-1}$. In total, carbon stock has increased by 15 tons $\mathrm{ha}^{-1}$ during 54 years. However, carbon stock changes are not statistically significant at $95 \%$ confidence level.

Soil carbon stock increase after drainage is reported also by other researchers for the boreal region in Finland (Minkkinen \& Laine, 1998b; Ojanen et al., 2010; Lohila et al., 2011). Although drainage accelerates organic matter decomposition, it can be compensated by higher aboveground and belowground litter production rates followed by an increased tree biomass growth.

The growing stock at the control site $\sim 50 \mathrm{~m}^{3} \mathrm{ha}^{-1}$, but the growing stock at the drained site is at least four times higher $\left(\sim 220 \mathrm{~m}^{3} \mathrm{ha}^{-1}\right)$. It promotes higher litter production rates in the drained sites. Tree biomass growth and subsequent increase of litter production rate contribute to the increased carbon allocation into soil. Results show the formation of stable litter layer $(\sim 3-4 \mathrm{~cm})$ on soil surface in the drained sites. At the control site, no litter layer was observed. Furthermore, a considerable quantity of carbon in the soil is allocated in the root biomass (Laiho \& Finér, 1996; Bardulis, Jansons, \& Liepa, 2012; Bardulis et al., 2015), especially through fine root production/ mortality. Fine roots may even contribute to $\sim 70 \%$ from the total carbon cycle in forest ecosystem (Gower, Pongracic, \& Landsberg, 1996; Bhuiyan et al., 2016).

The shrinkage of peat is followed by an increased soil bulk density (Figure 2). Bulk density in topsoil $(0-10 \mathrm{~cm})$ has increased almost twice from $75 \mathrm{~kg} \mathrm{~m}^{-3}$ to $141 \mathrm{~kg} \mathrm{~m}^{-3}$. Differences of bulk density tend to decrease in deeper soil layers. However, differences are still significant at $20-40 \mathrm{~cm}$ depth. Furthermore, it seems that the impact of drainage may extend even deeper than the studied $0-80 \mathrm{~cm}$ soil profile. Although the difference of bulk density is not significant at the sampling depth $40-80 \mathrm{~cm}$, still this difference is $23 \mathrm{~kg} \mathrm{~m}^{-3}$. Similar results are reported

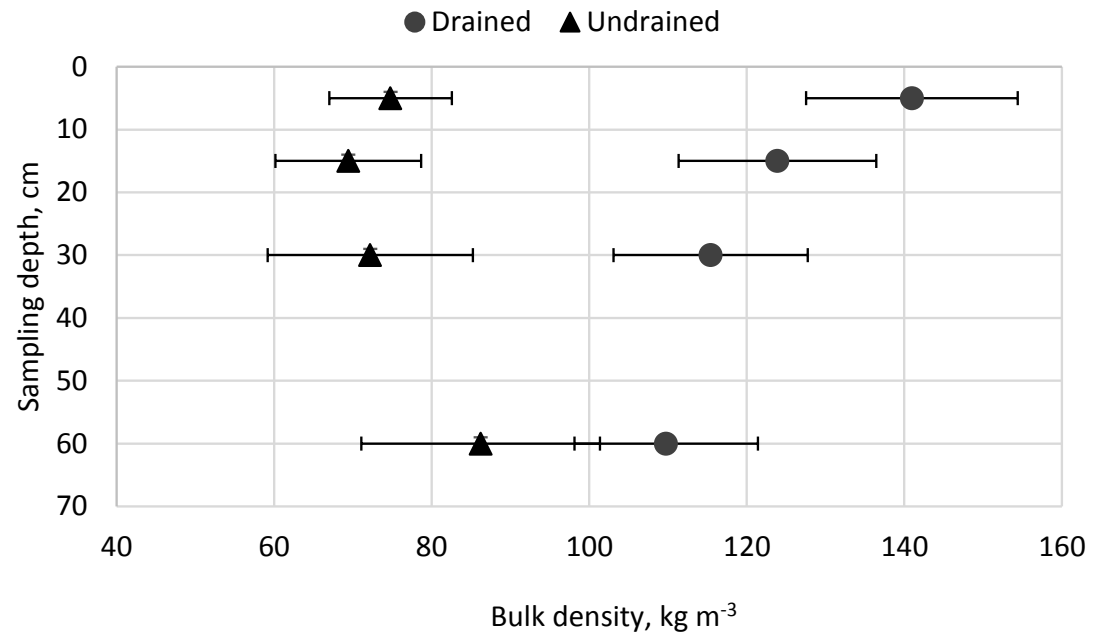

Figure 2. Soil bulk density in drained and undrained plots at different sampling depths.

Results show mean \pm CI for normal distribution at confidence level 95\%. 


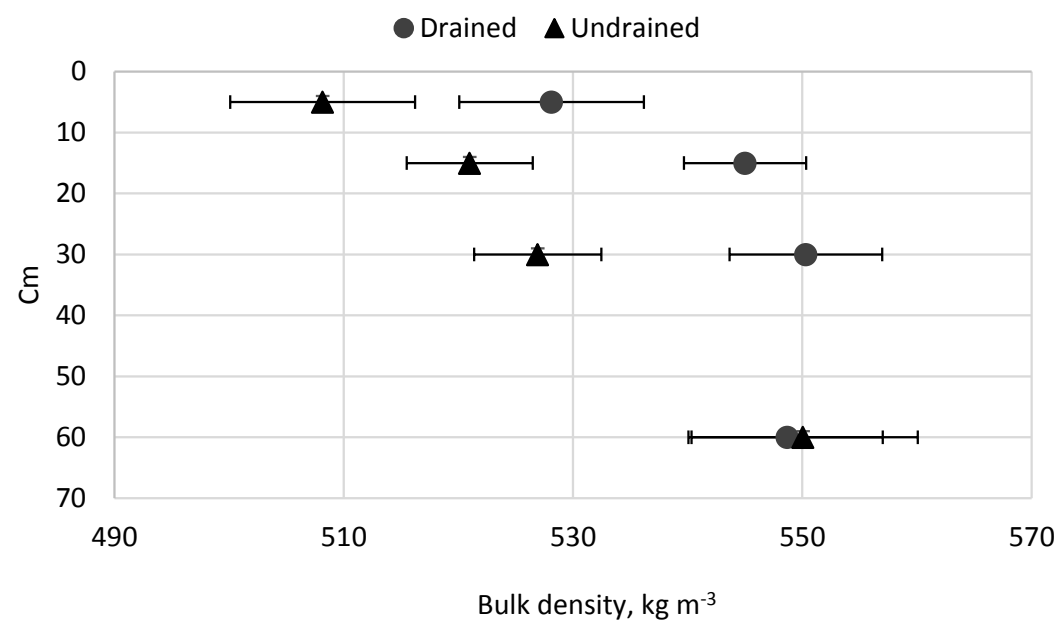

Figure 3. Carbon content in soil in drained and undrained plots at different sampling depths. Results show mean \pm CI for normal distribution at confidence level $95 \%$.

by Minkkinen and Laine (1998a), who found that soil compaction may occur also deeper than $80 \mathrm{~cm}$.

It was expected that carbon content $\left(\mathrm{g} \mathrm{C} \mathrm{kg}^{-1}\right)$ in peat will decrease after drainage due to oxidation and mineralization of organic matter. The results show an opposite trend. The carbon content at drained sites is higher compared to the control site (Figure 3 ) and the difference is statistically significant in $0-40 \mathrm{~cm}$ soil layer. Carbon content at the drained site varies from $528 \mathrm{~g} \mathrm{C} \mathrm{kg}^{-1}$ in the $0-10 \mathrm{~cm}$ layer to $550 \mathrm{~g} \mathrm{C} \mathrm{kg}^{-1}$ in $20-40 \mathrm{~cm}$ layer. Carbon content in the control site varies from $508 \mathrm{~g} \mathrm{C} \mathrm{kg}^{-1}$ in $0-10 \mathrm{~cm}$ layer to $527 \mathrm{~g} \mathrm{C} \mathrm{kg}^{-1}$ in $20-40 \mathrm{~cm}$ layer. There are no differences at the deepest $(40-80 \mathrm{~cm})$ sampling depth.

These results may be explained by the vertical movement of easily dissolvable organic carbon compounds. Organic matter cycling on the soil surface is accelerated after drainage, and carbon from litter decomposition is penetrating from the soil surface into deeper soil layers (Charman, Aravena, \& Warner, 1994; Domisch et al., 1998) and is subsequently stored there. Carbon content increase is reported also by Minkkinen (1999), who reports that the carbon content in peat has increased by $1.6 \%$, while our results show even higher rates of increase $-4.1 \%$.

It is necessary to do further research to get a better understanding about factors controlling the net balance of $\mathrm{CO}_{2}$ in drained forest organic soils. Literature analysis shows a strong impact of climate and fertility gradient on the net $\mathrm{CO}_{2}$ exchange. Still, there are lot of unanswered questions about controls which determine, whether soil after drainage will become source or will keep acting as a sink. More accurate information about the impact of soil temperature, moisture, drought, fertility, microbial activity etc. on $\mathrm{CO}_{2}$ exchange would help us to model those processes and help to develop more accurate emission factors for national GHG inventory. Furthermore, it may contribute to thedevelopment of a more sustainable management of drained forests on organic soils.

\section{Conclusions}

In the hemiboreal vegetation zone, drainage of organic soils is not always causing carbon storage reduction. Carbon stock may even increase after the drainage. This is caused by the increase of above and belowground litter production rates. Subsidence followed by drainage is caused mostly by physical shrinkage of aerated soil surface not by peat oxidation.

\section{Acknowledgments}

The study is financially supported by Latvian Ministry of Agriculture managed Forest Development Fund. Thanks to reviewer for contribution to improve language of the paper.

\section{References}

1. Armentano, T.V., \& Menges, E.S. (1986). Patterns of Change in the Carbon Balance of Organic SoilWetlands of the Temperate Zone. Journal of Ecology. 74 (3), 755 - 774. DOI: 10.2307/2260396.

2. Arnold, K., Nilsson, M., Hånell, B., Weslien, P., \& Klemedtsson, L. (2005a). Fluxes of CO2, CH4 and N2O from drained organic soils in deciduous forests. Soil Biology and Biochemistry. 37 (6), 1059 - 1071. DOI: 10.1016/j.soilbio.2004.11.004.

3. Arnold, K.V., Weslien, P., Nilsson, M., Svensson, B.H., \& Klemedtsson, L. (2005b). Fluxes of CO2, CH4 and N2O from drained coniferous forests on organic soils. Forest Ecology and Management. 210 (1 - 3), 239 - 254. DOI: 10.1016/j.foreco.2005.02.031. 
4. Bardulis, A., Jansons, A., \& Liepa, I. (2012). Below-ground biomass production in young stands of Scots pine (Pinus sylvestris L.) on abandoned agricultural land. Research for Rural Development. Annual 18th International Scientific Conference Proceedings. Volume 2. May 2012 (49 - 55). Jelgava, Latvia: Latvia University of Agriculture.

5. Bardulis, A., Lazdina, D., Daugaviete, M., Bārdule, A., Daugavietis, U., \& Rozītis, G. (2015). Above ground and below ground biomass in grey alder Alnus incana (L.) Moench. young stands on agricultural land in central part of Latvia. Agronomy research. 13 (2), 277 - 286.

6. Bhuiyan, R., Minkkinen, K., Helmisaari, H.-S., Ojanen, P., Penttilä, T., \& Laiho, R. (2016). Estimating fine-root production by tree species and understorey functional groups in two contrasting peatland forests. Plant and Soil. 1 - 18. DOI: 10.1007/s11104-016-3070-3.

7. Bridgham, S.D., Richardson, C.J., Maltby, E., \& Faulkner, S.P. (1991). Cellulose Decay in Natural and Disturbed Peatlands in North Carolina. Journal of Environmental Quality. 20 (3), 695 - 701. DOI: 10.2134/ jeq1991.00472425002000030032x.

8. Byrne, K.A., \& Farrell, E.P. (2005). The effect of afforestation on soil carbon dioxide emissions in blanket peatland in Ireland. Forestry. 78 (3), 217 - 227. DOI: 10.1093/forestry/cpi020.

9. Cannell, M.G.R., Dewar, R.C., \& Pyatt, D.G. (1993). Conifer Plantations on Drained Peatlands in Britain: a Net Gain or Loss of Carbon? Forestry. 66 (4), 353 - 369. DOI: 10.1093/forestry/66.4.353.

10. Charman, D.J., Aravena, R., \& Warner, B.G. (1994). Carbon Dynamics in a Forested Peatland in NorthEastern Ontario, Canada. Journal of Ecology. 82 (1), 55 - 62. DOI: 10.2307/2261385.

11. Comeau, L., Hergoualc'h, K., Smith, J.U., \& Verchot, L. (2013). Conversion of intact peat swamp forest to oil palm plantation: Effects on soil CO2 fluxes in Jambi, Sumatra. Center for International Forestry Research. DOI: 10.17528/cifor/004119.

12. Domisch, T., Finér, L., Karsisto, M., Laiho, R., \& Laine, J. (1998). Relocation of carbon from decaying litter in drained peat soils. Soil Biology and Biochemistry. 30 (12), 1529 - 1536. DOI: 10.1016/S00380717(97)00233-2.

13. Flanagan, L.B., \& Syed, K.H. (2011). Stimulation of both photosynthesis and respiration in response to warmer and drier conditions in a boreal peatland ecosystem. Global Change Biology. 17 (7), 2271 - 2287. DOI: $10.1111 /$ j.1365-2486.2010.02378.x.

14. Gorham, E. (1991). Northern Peatlands: Role in the Carbon Cycle and Probable Responses to Climatic Warming. Ecological Applications. 1 (2), 182 - 195. DOI: 10.2307/1941811.

15. Gower, S.T., Pongracic, S., \& Landsberg, J.J. (1996). A Global Trend in Belowground Carbon Allocation: Can We Use the Relationship at Smaller Scales? Ecology. 77 (6), 1750 - 1755. DOI: 10.2307/2265780.

16. Hargreaves, K.J., Milne, R., \& Cannell, M.G.R. (2003). Carbon balance of afforested peatland in Scotland. Forestry. 76 (3), 299 - 317. DOI: 10.1093/forestry/76.3.299.

17. Hiraishi, T., Krug, T., Tanabe, K., Srivastava, N., Baasansuren, J., Fukuda, M., \& Troxler, T.G. (2014). IPCC 2013 Revised Supplementary Methods and Good Practice Guidance Arising from the Kyoto Protocol: IPCC, Switzerland.

18. Hirano, T., Jauhiainen, J., Inoue, T., \& Takahashi, H. (2008). Controls on the Carbon Balance of Tropical Peatlands. Ecosystems. 12 (6), 873 - 887. DOI: 10.1007/s10021-008-9209-1.

19. Hommeltenberg, J., Schmid, H.P., Drösler, M., \& Werle, P. (2014). Can a bog drained for forestry be a stronger carbon sink than a natural bog forest? Biogeosciences. 11 (13), 3477 - 3493. DOI: 10.5194/bg11-3477-2014.

20. Hooijer, A., Page, S., Jauhiainen, J., Lee, W.A., Lu, X.X., Idris, A., \& Anshari, G. (2012). Subsidence and carbon loss in drained tropical peatlands. Biogeosciences. 9 (3), 1053 - 1071. DOI: 10.5194/bg-9-10532012.

21. Hooijer, S.P., Canadell, J, Silvius, M., \& Alm, J. (2009). Current and future CO2 emissions from drained peatlands in Southeast Asia. Biogeosciences. 7 (4). DOI: 10.5194/bgd-6-7207-2009.

22. Indriksons, A. (2009). Cycle of biogenous elements in drained forests. Academic dissertation, Latvia University of Agriculture, Jelgava, Latvia.

23. Jauhiainen, J., Kerojoki, O., Silvennoinen, H., Limin, S., \& Vasander, H. (2014). Heterotrophic respiration in drained tropical peat is greatly affected by temperature-a passive ecosystem cooling experiment. Environmental Research Letters. 9 (10), 105013. DOI: 10.1088/1748-9326/9/10/105013.

24. Laiho, R., \& Finér, L. (1996). Changes in root biomass after water-level drawdown on pine mires in southern Finland. Scandinavian Journal of Forest Research. 11 (1-4), 251 - 260. DOI: 10.1080/02827589609382934.

25. Laiho, R., \& Laine, J. (1994). Nitrogen and phosphorus stores in Peatlands drained for forestry in Finland. Scandinavian Journal of Forest Research. 9 (1 - 4), 251 - 260. DOI: 10.1080/02827589409382838. 
26. Leifeld, J., Müller, M., \& Fuhrer, J. (2011). Peatland subsidence and carbon loss from drained temperate fens. Soil Use and Management. 27 (2), 170 - 176. DOI: 10.1111/j.1475-2743.2011.00327.x.

27. Lieffers, V.J. (1988). Sphagnum and Cellulose Decomposition in Drained and Natural Areas of an Alberta Peatland. Canadian Journal of Soil Science. 68 (4), 755 - 761. DOI: 10.4141/cjss88-073.

28. Liepa, I. (1996). Pieauguma mācība. (Increment science) LLU, Jelgava. (in Latvian).

29. Lohila, A., Laurila, T., Aro, L., Aurela, M., Tuovinen, J.-P., Laine, J., \& Minkkinen, K. (2007). Carbon dioxide exchange above a 30-year-old Scots pine plantation established on organic-soil cropland. Boreal Environment Research. 12, 141 - 157.

30. Lohila, A., Minkkinen, K., Aurela, M., Tuovinen, J.-P., Penttilä, T., Ojanen, P., \& Laurila, T. (2011). Greenhouse gas flux measurements in a forestry-drained peatland indicate a large carbon sink. Biogeosciences. 8 (11), 3203 - 3218. DOI: 10.5194/bg-8-3203-2011.

31. Lukkala, O.J. (1949). Soiden turvekerroksen painuminen ojituksen vaikutuksesta (The peat subsidence after peatland drainage). Metsätieteellisen tutkimuslaitoksen julkaisuja. 37, 1 - 67. (in Finnish) Retrieved March 10, 2017, from: http://jukuri.luke.fi/handle/10024/522863. (in Finland).

32. Minkkinen, K. (1999). Effect of forestry drainage on the carbon balance and radiative forcing of peatlands in Finland. Academic dissertation, University of Helsinki, Helsinki, Finland.

33. Minkkinen, K., Korhonen, R., Savolainen, I., \& Laine, J. (2002). Carbon balance and radiative forcing of Finnish peatlands 1900 - 2100 - the impact of forestry drainage. Global Change Biology. 8 (8), 785 - 799. DOI: 10.1046/j.1365-2486.2002.00504.x.

34. Minkkinen, K., \& Laine, J. (1998a). Effect of forest drainage on the peat bulk density of pine mires in Finland. Canadian Journal of Forest Research. 28 (2), 178 - 186. DOI: 10.1139/x97-206.

35. Minkkinen, K., \& Laine, J. (1998b). Long-term effect of forest drainage on the peat carbon stores of pine mires in Finland. Canadian Journal of Forest Research. 28 (9), 1267 - 1275. DOI: 10.1139/x98-104.

36. Minkkinen, K., Laine, J., Shurpali, N.J., Mhkiranta, P., Alm, J., \& Penttilä, T. (2007). Heterotrophic soil respiration in forestry-drained peatlands. Boreal Environment Research. 12 (2), 115 - 126.

37. Minkkinen, K., Vasander, H., Jauhiainen, S., Karsisto, M., \& Laine, J. (1999). Post-drainage changes in vegetation composition and carbon balance in Lakkasuo mire, Central Finland. Plant and Soil. 207 (1), 107 - 120. DOI: 10.1023/A:1004466330076.

38. Ojanen, P., Minkkinen, K., Alm, J., \& Penttilä, T. (2010). Soil-atmosphere CO2, CH4 and N2O fluxes in boreal forestry-drained peatlands. Forest Ecology and Management. 260 (3), 411 - 421. DOI: 10.1016/j. foreco.2010.04.036.

39. Ojanen, P., Minkkinen, K., \& Penttilä, T. (2013). The current greenhouse gas impact of forestry-drained boreal peatlands. Forest Ecology and Management. 289, 201 - 208. DOI: 10.1016/j.foreco.2012.10.008.

40. Pitkänen, J.T. (2013). Carbon storage change on a partially forestry-drained boreal mire determined through peat column inventories. Boreal Environment Research. 18, 223 - 234.

41. Rothwell, R.L., Silins, U., \& Hillman, G.R. (1996). The effects of drainage on substrate water content at several forested Alberta peatlands. Canadian Journal of Forest Research. 26 (1), 53 - 62. DOI: 10.1139/ x26-006.

42. Salm, J.-O., Maddison, M., Tammik, S., Soosaar, K., Truu, J., \& Mander, Ü. (2012). Emissions of CO2, $\mathrm{CH} 4$ and N2O from undisturbed, drained and mined peatlands in Estonia. Hydrobiologia. 692 (1), $41-55$. DOI: $10.1007 / \mathrm{s} 10750-011-0934-7$.

43. Schipper, L.A., \& McLeod, M. (2002). Subsidence rates and carbon loss in peat soils following conversion to pasture in the Waikato Region, New Zealand. Soil Use and Management. 18 (2), 91 - 93. DOI: 10.1111/ j.1475-2743.2002.tb00225.x.

44. Simola, H., Pitkänen, A., \& Turunen, J. (2012). Carbon loss in drained forestry peatlands in Finland, estimated by re-sampling peatlands surveyed in the 1980s. European Journal of Soil Science. 63 (6), 798 - 807. DOI: 10.1111/j.1365-2389.2012.01499.x.

45. Sundari, S., Hirano, T., Yamada, H., Kusin, K., \& Limin, S. (2012). Effect of groundwater level on soil respiration in tropical peat swamp forests. J. Agric. Meteorol. 68 (2), 121 - 134. DOI: 10.2480/ agrmet.68.2.6.

46. Turunen, J., Tomppo, E., Tolonen, K., \& Reinikainen, A. (2002). Estimating carbon accumulation rates of undrained mires in Finland-application to boreal and subarctic regions. The Holocene. 12 (1), $69-80$. DOI: 10.1191/0959683602hl522rp.

47. Wösten, J.H.M., Ismail, A.B., \& van Wijk, A.L.M. (1997). Peat subsidence and its practical implications: a case study in Malaysia. Geoderma. 78 (1 - 2), 25 - 36. DOI: 10.1016/S0016-7061(97)00013-X. 
48. Yu, Z., Loisel, J., Brosseau, D.P., Beilman, D.W., \& Hunt, S.J. (2010). Global peatland dynamics since the Last Glacial Maximum. Geophysical Research Letters. 37 (13), L13402. DOI: 10.1029/2010GL043584.

49. Zalitis, P., \& Indriksons, A. (2009). The hydrological properties of waterlogged and drained forests in Latvia. Journal of Water and Land Development. 13b, 69 - 86. DOI: 10.2478/v10025-010-0006-9.

50. Zalitis, P., Jansons, J., \& Indriksons, A. (2012). The dynamics of forest stand parameters in drained transitional mires. Forest science. 26. Retrieved February 6, 2017, from: http://agris.fao.org/agris-search/ search.do?recordID $=$ LV2013000379.

51. Zālītis, P., \& Jansons, J. (2013). Latvijas meža tipoloǵija un tās sākotne (Latvian forest typology and its origin). Daugavpils universitātes akadēmiskais apgāds Saule, Daugavpils. (in Latvian).

52. Zoltai, S.C., \& Martikainen, P.J. (1996). Estimated extent of forested peatlands and their role in the global carbon cycle. Forest Ecosystems, Forest Management and Global Carbon Cycle. 40, 47 - 58. DOI: 10.1007/978-3-642-61111-7_5. 